\begin{tabular}{|c|c|c|}
\hline Name & $\begin{array}{c}\text { Average copper } \\
\text { present } \\
\text { Per cent }\end{array}$ & $\begin{array}{l}\text { Copper found } \\
\text { Per cent }\end{array}$ \\
\hline Vanadium steel No. 24. & 0.022 & 0.020 \\
\hline Chrome nickel steel No. 32 . & 0.056 & 0.056 \\
\hline Chrome vanadium steel No. 30 . & 0.070 & 0.066 \\
\hline Nickel steel No. 33 . & 0.150 & 0.150 \\
\hline No. 5 A iron $(C)$. & 0.060 & 0.063 \\
\hline
\end{tabular}

As a further proof of the accuracy of this method, known amounts of pure electrolytic copper containing 99.88 per cent of copper were added to the Bureau of Standards' sample No. I4 A steel. The mixed drillings were dissolved in $20 \mathrm{cc}$. of (2-I) nitric acid, $8 \mathrm{cc}$. of sulfuric acid (sp. gr. I.84) added and the solution evaporated until sulfuric acid fumes were evolved freely. The solution was allowed to cool and then $25 \mathrm{cc}$. of cold water were added and the solution was heated until all the sulfate was dissolved. The solution was filtered and the filter washed with hot water. The volume (not to exceed $75 \mathrm{cc}$.) was brought to a boil and the sheet aluminum introduced. Procedure was the same as stated before, except that after the solution was decanted through the filter and washed with water, the copper was dissolved on the filter and the filtrate rece ved in an electrolytic beaker and electrolyzed as usual. The results obtained follow:

Copper added
Per cent
0.499
0.998
1.997
2.996
3.995
4.994

Copper found
Per cent
0.49
0.99
1.97
3.00
3.99
4.98

I wish to give credit to Mr. George Shuster of the laboratory force, who tried out this method and obtained the results stated above.

William B. PRICE

WATERBURY, CONN.

Oct. 25,1913

INTERNATIONAL ELECTRICAL CONGRESS, I9I5.

The International Electrical Congress is to be held at San Francisco, September 13-I8, I9I5, under the auspices of the American Institute of Electrical Engineers, by authority of the International Electrotechnical Commission and during the Panama-Pacific International Exposition. Dr. C. P. Steinmetz has accepted the Honorary Presidency of the Congress. The deliberations of the Congress will be divided among twelve sections which will deal exclusively with electricity and electrical practice. There will probably be about 250 papers. The first membership invitations will be issued in February or March, I9I4.

Attention is drawn to the distinction between this Electrical Congress and the International Engineering Congress which will be held at San Francisco during the week immediately following the electrical congress. The engineering congress is supported by the Societies of Civil, Mechanical and Marine Engineers and by the Institutes of Mining and Electrical Engineers, as well as by prominent Pacific Coast engineers who are actively engaged in organizing it. This Congress will deal with engineering in a general sense, electrical engineering subjects being limited to one of the eleven sections which will include about twelve papers, treating more particularly applications of electricity in engineering work.

The meeting of the International Electrotechnical Commission will be held during the week preceding that of the Electrical Congress.

\section{SPRING MEETING OF THE AMERICAN CHEMICAL SOCIETY}

The Forty-ninth General Meeting of the American Chemical Society will be held in Cincinnati, Ohio, April 8-11, 1914.
The officers of the local section are: President, F. W. Weissmann, 2900 Vine St., Cincinnati, Ohio, and Secretary, Stephan J. Hauser, I623 Maple Avenue, College Hill, Cincinnati, Ohio. A more complete statement of the meeting will appear in the March issue of This Journal. The titles of papers should be sent to the Secretary, Charles L. Parsons, Box 505, Washington, D. C.

The following chairmen of committees have been appointed: Executive Committee, Frederick W. Weissmann.

Finance Committee, Archibald Campbell.

Transportation and Excursions, Gordon Farnham.

Press, Publicity and Printing, C. T. P. Fennel.

Reception and Registration, J. W. E1lms.

Ladies' Reception, Mrs. J. W. Ellms.

Entertainment, Richard Lord.

Smoker, F. C. Broeman.

Banquet, L. W. Jones.

Meeting Places, John Uri Lloyd.

Chas. L. Parsons

\section{BUREAU OF STANDARDS' ANALYZED SAMPLES}

The Bureau of Standards, Washington, D. C., is prepared to issue a sheet brass of the following composition, approximately:

\begin{tabular}{|c|c|c|}
\hline & Per cent & Per cen \\
\hline & 1.0 & Zinc. \\
\hline Lead. & 1.0 & Iron. ....... \\
\hline Copper & 70.3 & Nickel... \\
\hline
\end{tabular}

The fee, payable in advance is $\$ 3.00$ per sample of about I 50 grams weight.

January 6,1914

S. W. Stratton, Director

\section{SYNTHETIC RESINS-CORRECTION}

We note the following errors in our article under the above title, This Jorknal, 6, 3 .

(1) Page 8, Column I, four lines from the end, the equation should read:

" $2 \mathrm{HO} \cdot \mathrm{CH}_{2} \cdot \mathrm{C}_{6} \mathrm{H}_{4} \mathrm{OH} \longrightarrow \mathrm{HO} \cdot \mathrm{CH}_{2} \cdot \mathrm{C}_{6} \mathrm{H}_{4} \mathrm{O} \cdot \mathrm{CH}_{2} \cdot \mathrm{C}_{6} \mathrm{H}_{4} \mathrm{OH}$."

(2) Page ro, Column I, below the first table: " $\mathrm{C}_{6} \mathrm{H}_{3} \mathrm{OCH}_{2} \cdot \mathrm{C}_{6} \mathrm{H}_{4} . \mathrm{OCH}_{2} \cdot \mathrm{C}_{6} \mathrm{H}_{4}() \mathrm{OCH}_{2} . \mathrm{C}_{6} \mathrm{H}_{4} \mathrm{OH}$."

(3) Page ${ }_{13}$, Column 2, line nine from the end: "79 per cent" should read 76 per cent.
L. V. REDMAN
A. J. WEITH
F. P. BROCK

January 21,1914

\section{VEGETABLE OILS EXPORTED FROM CHINA, I9I2}

The Oil, Paint and Drug Reporter states that exports of vegetable oils from China in 1912 amounted to 35,046 net tons of bean oil, 20,28I net tons of peanut oil, and 44,815 tons of wood, tea seed and other oils.

\section{ANNUAL TABLES OF CONSTANTS, ETC., VOL. III.}

Volume III of the Annual Tables of Constants and Numerical Data, Chemical, Physical and Technological, published by the International Commission of the VIIth and VIIIth International Congresses of Applied Chemistry is now in press and will be issued in the first half of I9I4. A descriptive circular with references to reviews of previous volumes may be secured on application to The University of Chicago Press.

The subscription to Volume III is now opened and will be closed March 3I, 19I4. The names of subscribers should be sent to The University of Chicago Press, the American agent for the distribution of the Annual Tables. Subscriptions are payable to The University of Chicago Press at the time of publication.

The subscription price of Volume III will be the same as for Volume II, namely, $\$ 6$ for the unbound copy, $\$ 6.80$ for the 